\title{
THE LESSONS OF MIDDLE EAST INVOLVEMENT
}

\author{
Mark A. Larson ${ }^{1}$, University of Minnesota
}

Despite the oft-used phrase, history does not repeat itself. What history does do, however, is offer us lessons. If we do not learn history's lessons, we will repeat the mistakes of history thereby making it appear that history is indeed repeating itself. Nowhere is this more clear than in the Middle East. To find historical lessons in the Middle East, one should begin by studying the events of World War I. It was during World War I that the composition of the Middle East changed from the indirectly ruled Ottoman Empire, to the collection of nation states that we know today. It is quite fashionable to blame Britain for the outcome of, and all future problems with, this new Middle East. It has become more fashionable to transform the blame in the present age to the United States. In this paper, I will analyze British involvement in the Middle East; beginning with the contradictory wartime agreements that Britain made which would eventually change the shape of the Middle East. I will argue that the problems in the Middle East cannot be blamed solely, or even mostly, on the British or on the Western power who had inherited this blame, the United States. In conclusion, I will develop lessons of history from this period of British involvement in the Middle East; lessons that the United States has yet to learn.

Prior to the war, the Ottomans and British were the two main powers in the Middle East. Due to the rise of nationalism in the Balkans, and British control in Egypt and Arabia, Ottoman control of the region was in decline in this period. The Ottomans were allocating their resources to other parts of their empire, in particular the Balkans,

\footnotetext{
${ }^{1}$ Mark A. Larson is a Ph.D. candidate in the Hubert H. Humphrey Institute of Public Affairs at the University of Minnesota.
} 
and relied on a policy of playing the various Arab factions against one another to retain control of their holdings in the Arab territories.

On March 9, 1914, the Ottomans signed a treaty with the British. This treaty divided the region into two spheres of influence with a line running from the eastern part of Yemen to Qatar. The Ottomans controlled the area north of this line and the British controlled the area south of this line. The British wanted to preserve, but weaken, the Ottoman Empire, as was always British policy in the region. Beginning with the Great Game, Britain always saw the Ottoman Empire as the best way to control Russian ambitions in the region. This agreement did not affect the various Arab tribal chiefs who were the local powers in the area. At any rate, the ink was barely dry on this treaty when war broke out and this treaty was nullified.

The Ottoman decision to enter World War I was the single most important event in the history of the Middle East (Yapp, 1987, 266). This decision, and the subsequent defeat of the Ottoman Empire, would bring an entirely different political structure to the region. The Ottoman decision to enter the war needs further exploration. It was not a natural decision to enter the war on the side of Germany. To the contrary, the Ottomans approached the other European powers about a possible alliance. The British were already quite involved with managing the finances of the empire, at Ottoman invitation. The deterioration of the empire, both territorial and economic, coupled with the process of modernization, led to the Young Turk revolution in 1908. The Ottomans were humiliated at these losses, especially in the Balkans to the Christian west, and believed the only way to survive was to become a protectorate of one of the Great Powers (Fromkin, 1989, 48). When the war began, the majority of the Ottoman ministers wanted to remain neutral in the war, at the very least until they saw a favorite emerge from the 
contest (Yapp, 1987, 266). In fact, the leadership of the Young Turks was very divided on whom to support in the war. Djavid Pasha, the Minister of Finance, sought an alliance with Britain, who was managing the empire's finances at this time. Djemal Pasha, the Marine Minister, sought an alliance with France. Talaat Pasha, the civilian chief, sought an alliance with Russia. Enver Pasha, the Minister of War, was the only Ottoman official who supported Ottoman entry into the war on the side of Imperial Germany. Enver believed that Germany would ultimately win the war, (an opinion not shared by Mustafa Kemal (Attaturk) who believed that the Allies would win), and that by entering the war on the side of Germany, the empire would reach new imperial heights in the post war settlement (Karsh \& Karsh, 1999, 138). Most of the other ministers did not want an alliance with the Allies, since they were for the most part anti-Russian; but at the same time they didn't want to fight Britain and France (Karsh \& Karsh, 107). This lack of consensus caused the Ottomans to remain neutral in the beginning of the war. Another reason for this early neutrality was that all of these propositions of alliance, including Germany, were refused by the European nations.

When the escaping German warships, the Goeben and the Breslau, were admitted into the Sea of Marmara, and subsequently brought into the Ottoman Navy, the Ottoman Empire became involved. A furious Britain believed that Germany was bullying the Ottomans to their side. This belief was incorrect. In fact, the Ottomans were bullying the Germans into an alliance (Fromkin, 1989, 64). The Ottomans told the Germans that unless six proposals were met, they would allow the British into the harbor and let them attack the German warships. The most important of these proposals was that the Ottomans would share in the spoils of war. The Germans didn't like the idea but had no other choice. On August 2, 1914, the Ottomans signed a secret treaty of alliance with 
Germany, hoping to keep control of their possessions in the Balkans from Austria, as well as to protect their eastern border from the Russians. In October of 1914, Enver Pasha ordered a bombardment of Russian ports along the Black Sea. This second event brought the Ottomans officially into the war on the side of the Germans, although even after this attack, Britain still believed war with the Ottomans was avoidable (Karsh \& Karsh, 1999, 137). Many German officials believed that the Ottomans were useless military allies. The German High Command held onto the alliance because they believed that the Ottomans could keep the Entente busy in the Middle East, thereby diverting Allied troops from the Western front. If the Entente forces were busy fighting the Ottomans in the Middle East, these forces could not be deployed to the trenches of Europe.

An analysis of the Ottoman entry into World War I shows that all sides were to blame. In the end, the Ottomans need to bear some of the blame for the making of the new Middle East. It is, of course, impossible to say what would have happened if the Ottomans did remain neutral, but it is probable that their empire would have been preserved. This policy of using the Ottoman Empire as a buffer against Russia would have been even more likely following the Bolshevik Revolution. Britain never really wanted to fight the Ottomans in the first place. Two years after the bombardment of the Russian ports, British Prime Minister Lloyd George was negotiating an Ottoman exit of the war with Enver Pasha. The Ottomans, particularly Enver, were wrong to assume that Britain wanted a fight with them, just as they were wrong to assume that Germany would win the war and ultimately share in the spoils of war. Again, it is impossible to guess what would have happened in the Middle East if the Germans had won the war, but it is difficult to imagine that the Ottomans would have been given more territory and even if they were, that territory probably would have been under German tutelage. Indeed, the 
Ottoman decision to enter the war ironically had the opposite effect. Instead of bringing the empire to new heights, it brought the empire to a new low, extinction.

The British should also bear some of the blame of Ottoman entry into the war for not agreeing to a formal alliance with the Ottomans from the beginning. The British got involved in the war in the Middle East with the goal of attacking the Axis powers form the south and making the Germans fight on two fronts. Again, it's impossible to say what would have happened if the British-Ottoman alliance would have occurred. But it could have ended up saving numerous lives on the Eastern, as well as Western fronts, by shortening the war. Ironically, it was the British who would end up diverting resources to a two-front war. It was the Germans who were able to commit all of their resources to the trenches of the Western front while their Ottoman allies engaged the British in the Middle East.

In addition to the better-known agreements to divide up the region, Britain also made agreements with Russia and Italy that concerned the make up of the post-war Middle East. The British believed that the key to victory on the Eastern Front was Russian entry into the war. The British strategy to achieve this was to give Russia a worthwhile prize for which to fight. The entry of the Ottoman Empire into the war gave the British a prize to offer the Russians: Istanbul and the Dardanelle Straits. In November of 1914, the British and French ambassadors in Moscow informed the Russian Foreign Minister that Russia would be allowed to settle the matter of Istanbul and the Straits in the manner she choose. Some historians believe that the British and French did not intend to honour this promise and would push for an internationalization of the Straits following the war (Yapp, 1987, 275). These assurances were given in the form of notes known as the Constantinople Agreement in March of 1915. 
On November 14, 1914, the Ottoman Sultan called for a holy war by all Muslims to attack the infidels living in the Christian territories in the Middle East. The British responded to this call for a holy war by attacking the Dardanelles in an attempt to open the straits and forge a route with which to attack Istanbul. Although the campaign was a military failure, it did have one success; it persuaded Italy that she should join the Entente (Yapp, 1987, 278). Italy's main goal was to gain territory at the head of the Adriatic Sea at the expense of Austria. Italy did not want to be left out of the post-war partition of the Middle East, and in April of 1915, the Treaty of London was signed. This treaty agreed that Italy could keep the Dodecanese Islands, which she occupied in 1912, and also receive a sphere of influence in Adalia in the western part of Asia Minor at the end of the war. Subsequent agreements gave Italy Izmir and Konya but these agreements were subject to Russian approval, which was never obtained, and Britain and France claimed that no further promises had been made to Italy.

These agreements are important for two reasons. First, they are blueprints of the later, more famous, or infamous, agreements which Britain signed. The British were offering pieces of the Ottoman Empire as incentive to woo potential allies. At this early stage of the war, the British could not have been sure of an allied victory. The British were promising territory to one nation, which belonged to another nation, whom Britain could not have been sure of ultimately defeating, in an attempt to gain allies with whom to fight the Germans. The second, and more important reason is that these territorial payments to Russia and Italy meant that Britain and France would seek their own compensation from Ottoman territory following the war (Yapp, 1987, 276).

When the British attacked the Dardanelles, the Ottomans launched a counter attack on the British holdings at the Suez Canal. The Ottomans hoped that this would stir 
up the Muslims and cause an uprising against British control in Egypt. The attack and, the plan for a pan Islamic uprising were equally unsuccessful. The Ottomans launched a similar attack in 1916. These attacks were only effective in scaring the British into seeking an ally in the Middle East.

Sharif Hussein had everything the British were looking for in an Arabian ally. He was from the Quraysh tribe, and was therefore descended from the prophet Mohammed and had a valid claim to be a leader of Muslims everywhere. He was the current Sharif of Mecca, the holiest city to Muslims, and could keep the pilgrim route open for the Muslims in the Entente nations. Most importantly, an uprising in the western part of Arabia led by Hussein would tie down the Ottoman army and make a renewal of the Ottoman attack on British interests in Egypt unlikely (Yapp, 1987, 216-222). In February of 1914, Hussein sent his son Abdullah to seek British support for his goals of an independent kingdom in the Middle East. At this point, it seemed very likely that the Ottomans were going to enter the war on the German side, and the British instructed their authorities in Egypt to open contacts with Hussein. The British promised Hussein that they would not intervene in any revolt in Arabia and would in fact support this Arab rebellion if the 'Arab nation' assisted with British efforts during the war.

In the summer of 1915, these negotiations took a more serious turn. Abdullah changed his demands and insisted that the British approve a post-war caliphate, ruled by Hussein. This caliphate would include an independent Arab nation spanning from Cilicia in the north to the Indian Ocean in the south, and from the Mediterranean in the west to Iran in the east. Britain agreed with forming a caliphate ruled by Hussein, but thought it was premature to discuss any questions of the boundaries of an independent Arab nation. Although a few months prior, Britain had promised specific territory to Italy and Russia. 
Hussein sent a letter saying that the territorial demands were a necessary requirement of any agreement between he and the British. He added that the territorial demands came not from him, but came from the Arab people.

In October of 1915, the British High Commissioner in Egypt, Sir Henry

McMahon, agreed, with certain reservations, "to recognize and support the independence of the Arabs within the territories included in the limits and boundaries proposed by the Sharif of Mecca". It was in these letters, known as the McMahon Hussein Correspondence, that Britain was to be seen as a villain in the Middle East for years to come. It is quite unfair, however, to make Britain the only villain for the McMahon Hussein Correspondence. A further analysis of the McMahon Hussein Correspondence paints a quite different picture.

To truly understand Britain's behaviour in these negotiations, we need to first look at the Ottoman military officer Lieutenant Mohammed Sharif Al Faruki. Not much is known of Al Faruki. What is known is that Al Faruki deserted the Ottoman Army at Gallipoli and went to Cairo. He told said that he had some important information for the British officials in Cairo. He told the British of a vast secret Arab society. This society, of which ninety percent of the Ottoman officer corps belonged, wanted to create an independent Arab caliphate in Arabia, Syria and Iraq. If the British supported Hussein's ambitions, Lieutenant Al Faruki assured them, these officers would defect and assist the British in Arabia. If the British refused, these same officers would turn to Germany for support. Because this story seemed to match Hussein's story, the British foolishly believed him. In fact, Hussein had no army, no secret societies, and no following (Fromkin, 1989, 177). Talk of rallying hundreds of thousands of Arabs, whether Hussein and Al Faruki believed it or not, was sheer fantasy. Despite the Turkification policy of 
the Young Turks and the crushing of Arab dissent by Djemal Pasha in the Levant, most Arabs remained loyal to the Ottomans throughout the war.

Prior to turning to the British for an alliance, Hussein learned that the Young Turks, who were busy crushing Arab dissent throughout the empire, planned to depose him. He had no choice to rebel no matter what Britain pledged to give him (Fromkin, 1989, 185). Even after he began his rebellion, he continued to negotiate with the Ottomans and offered to halt the rebellion if his Sharifate in Mecca was made hereditary. If anything, Hussein was lying to Britain about his intentions, not the other way around.

In reading the McMahon Hussein Correspondence, Britain really committed to nothing. Britain said that she could promise nothing to the detriment of her ally France or the other Arab chiefs with whom she had agreements (Fromkin, 1989, 183). Although Russia and Italy were not mentioned, Britain must have been thinking of these prior agreements. Also, Britain pledged to support Arab independence only if Hussein could stir up an Arab rebellion. As mentioned above, this rebellion never happened. In fact, the so called Great Arab Revolt didn’t even carry Medina. The British also implied that the independent Arab nation was to be subject to British advice and assistance.

Aside from his counter negotiations with the Young Turks, Hussein needs to shoulder more blame. Hussein never wanted independence for the Arabs; he wanted his own Hashemi rule for the Arabs. From the beginning, he called himself "King of the Arabs", which was simply not true. In fact, years later, Ibn Saud, his rival to the east, would defeat him and chase him out of the Arabian Peninsula. Hussein was not even King of the Neighbourhood. The revolt never had anything to do with any idea of nationalism. It was the glitter of British gold that rallied the Hijazi Bedouins behind the revolt, not the idea of any type of Pan Arab nationalism (Karsh \& Karsh, 1999, 191). 
Fromkin (223) puts the cost of this rebellion to the British at $£ 11$ million, an equivalent of $\$ 400$ million today. This a high price to pay for an ineffective operation that was really the imperialist vision of a local leader who represented little more than himself (Karsh \& Karsh, 1999, 184). Hussein knew the Young Turks would depose him so he turned to Britain and tried to strike the best deal he could. While the British were paying him handsomely, he went behind their backs and attempted to strike a better deal with the Young Turks. If the British can be blamed for anything, it is their mistaken belief of a vast Arab, Muslim conspiracy (Fromkin, 1989, 275). It was the British fear of, and desire to harness, Pan Islam and Pan Arabism that led to the McMahon Hussein Correspondence. Britain wished to ally herself with this secret society and have it work for her, not against her. It was this mistaken belief that not only cost Britain monetarily, but would also continue to haunt the Middle East for years to come.

One of the important effects of the McMahon Hussein Correspondence is that Britain needed France's consent. Britain responded to this needed French consent the same way she responded every time she needed consent during the war; she promised Ottoman territory. In what would become known as the Sykes Picot Agreement, the French claim was submitted very quickly. France wanted Syria. France saw itself as the protector of the Christian prior, particularly the Catholic Maronite Christians, in the Levant. Prior to Ottoman entry into the war, Francois Georges-Picot had lobbied for an armed uprising of the Maronites and a French expeditionary force be sent to Syria to contain any British intentions in the region. The French deluded themselves (Fromkin, 1989, 190-191). Not only did most people in Syria not see the French as their protectors, but also most were vehemently opposed to French rule. Britain agreed with the French claim to Syria because Sir Mark Sykes wanted the French to form a wall in the northern 
part of the Middle East between Russia and the British holdings in Arabia and India (Fromkin, 1989, 190-191).

Britain was a little slower to present her claim. Britain had various minor goals she hoped to gain at the war's conclusion. These goals, however, were modest compared to French annexation of the Levant and the government set up a committee led by Sir Maurice de Bunsen to consider more far-reaching goals. One of the members of this committee, Sir Mark Sykes, concluded that Iraq should be the centre of British aspirations. He saw the region as the logical extension of the present British position in the Persian Gulf. Another line of reasoning was that Iraq was an extension of the British Indian sphere of influence in the east. Sykes went on to suggest that the British possession in Iraq should be supplied from the Mediterranean Sea to the west, not from the Indian colony to the east. This made it necessary for the British to demand a port on the Mediterranean Sea, which Sykes suggested be Haifa. Agreement was never reached on Palestine and in the end; it was to be governed by some sort of international administration. Interestingly, there was no mention of the Jews living in Palestine at the time anywhere in the Sykes Picot Agreement (Fromkin, 1989, 196).

Britain began official negotiations with France in November of 1915. France was given Cicilia, coastal Syria, and Lebanon and a sphere of influence that stretched eastward to Mosul in a projected independent Arab state. Britain gained Basra, Baghdad, and a similar sphere of influence in the southern Middle East. Britain also received Haifa and Acre; the rest of Palestine would be placed under an unspecified international administration. Russia was brought into these negotiations in 1916. When the Russians saw the extent of the British and French claims she demanded, and was given, the Kurdistan and Armenia. Much is made of Britain's future desire to undo the Sykes Picot 
agreement, but it was Picot who, immediately after the negotiations, traveled to Russia and negotiated an agreement with Russia that France would get Palestine following the war.

In an analysis of the Sykes Picot agreement, Britain and France should both be blamed for being naïve. In 1915, the war was nowhere near victory and neither nation could count on an allied victory anywhere, let alone in the Middle East. It is hard to believe that either side thought the agreement binding. The French immediately began secret negotiations with Russia to undo the agreement. Later British behaviour also made it clear that neither side was very happy with the deal. It is also alleged that the British and French sold out the Arabs. It is interesting to note that the agreement contained a passage that granted Arab independence in the interior of the region. This was the first time any power, including the Ottomans to whom most of the Arabs remained loyal, ever considered independence for the Arabs (Fromkin, 1989, 185). In addition, the French, and later the British, were attempting to sell out one another, not the Arabs.

Of all the wartime negotiations, it is perhaps the Balfour Declaration that has caused the greatest controversy in the region. This declaration was contained in a letter sent to a prominent Zionist, Lord Rothschild, by British foreign secretary Lord Balfour. In this letter, Balfour promised that Britain would "look favourably" on "a national home for the Jewish people" in Palestine subject to two provisions. The first provision was that the national home would not interfere with the civil or religious rights of existing residents in Palestine. The second provision stated that the national home would not affect the political status of Jews in any other nation. It is interesting to note that the Balfour Declaration was not the first time a nation toyed with the idea of a Jewish homeland in Palestine. In 1917 the French Foreign Minister Jules Cambon told the 
Zionists that the French "feel sympathy for your cause" (Morris, 2001, 74). Certainly the words "look favourably" are no stronger or binding than "feel sympathy". Yet it was the British, who would be given a mandate in Palestine, and the Balfour Declaration who for years would be blamed for the situation in the Middle East.

Much has been made of just why Balfour wrote these words. Some believe that it was a political move to garner the support of Jews in the United States and Russia. At this time, Mark Sykes believed that an allied victory was unlikely and that the Jews could tip the balance (Fromkin, 1989, 197). Following the Bolshevik Revolution, the Balfour Declaration was seen as a way to keep the Russians in the war on the side of the Allies. With England fighting for a Jewish homeland, the Jewish populations in Russia might push their nation for greater involvement in the war. Similarly, the Jews in the United States would push for American entrance into the war. Just as the British believed in the power of a vast Arab conspiracy, they also believed in the power of a vast Jewish conspiracy. In fact, the British ambassador in Turkey believed that the Young Turk Revolution was the work of an international conspiracy of Jews, Freemasons and Zionists (Segev, 1999, 38). Just as the plan to control these ethnic conspiracies did not work with the Arabs, it did not work with the Jews. The Russians did not come back into the war. And the United States was slow to enter the war. 13.4 million people immigrated to the US from 1900-1914. Many of these were form belligerent countries in World War I and they were opposed to a US alliance with the Allies (Smith, 1999, 51). Also, there was a prevalence of anti-Semitism in the US at this time (Christison, 1999, 24). President Wilson was against the idea of Zionism because it conflicted with his idea of selfdetermination. His advisor, Colonel Edward Mandell House, added It is all bad and I told Balfour so. They are making (The Middle East) a breeding place for future war (Morris, 2001, 73). 
More importantly, only 1\% of the world's Jews were Zionists (Fromkin, 1989, 294). When the United States eventually entered the war, they remained at peace with the Ottoman Empire. The King Crane Commission Report said that the United States was indifferent to the idea of Zionism. They added that Palestine should not be separated from Greater Syria. They said, “(greater) Syria offers an excellent opportunity to establish a state where members of the three great monotheistic religions can live together in harmony." Detaching Palestine from Syria would only inflame religious conflict. The authors believed that the "obvious plan" was for Faisal to rule Greater Syria. They concluded their opinions about Zionism by stating that if a Jewish majority ever came to be in Palestine, the Christian and Muslim population would need protection from the Jewish population.

I believe that the real story behind British support of the Balfour Declaration starts with Lloyd George's assumption of the Prime Ministership. In fact, Lloyd George would later brag that Palestine was not even on the agenda until he became Prime Minister (Segev, 1999, 37). Lloyd George wanted to undo the Sykes Picot agreement and keep the French out of the Levant. He claimed that the agreement was not binding and that physical possession after the war was all that mattered (Fromkin, 1989, 267). Lloyd George believed that Zionism was a hugely influential political power with whose goodwill was worth any price to form an alliance (Segev, 1999, 38). The Balfour Declaration was a way to garner this power and court world opinion. Just as the French tried to gain an upper hand in Palestine with their secret agreement with Russia, the British were now trying to gain an upper hand by making an agreement with the Zionists. The declaration had nothing to do with Britain's support of world Jewry. The Zionist leader in Britain, Weizman, discovered a way to extract acetone, which was needed in the 
manufacture of explosives, from maize. Later George would call the Balfour Declaration a reward from a generous ruler to his court Jew (Segev, 1999, 43). When Balfour was Prime Minister in 1905, he sponsored laws to restrict immigration to Britain, which caused him to be branded an anti-Semite (Segev, 1999, 40-41).

An analysis of the Balfour Declaration reads quite similar to the McMahon Hussein Correspondence. Like its predecessor, the Balfour Declaration was basically meaningless and committed Britain to nothing (Yapp, 1987, 290). If the provisions were taken seriously, nothing could have been done that did not affect the rights of the current residents in Palestine. The language was equally vague. Just what did "look favourably" on a "national homeland" mean? In addition, Britain saw the declaration as just another in a long line of wartime documents that would have to be settled in negotiations following the conclusion of the war. No sooner was in published, that it was forgotten by all except the Zionists (Yapp, 1987, 291).

Much attention has been given to the Balfour Declaration's treatment of the native Arab population in Palestine. Yet others were also very involved in this treatment of the Palestinians. Hussein's son Faisal, wishing to become a king in Syria (of which Palestine was currently a part) and seeking to fend off French claims in the region, agreed with Weizman to a "racial kinship and ancient bonds" with his Jewish brothers (Morris, 2001, 79-80). He agreed to share Palestine with the Zionists. T.E. Lawrence, better known as 'Lawrence of Arabia', disagreed with this decision (Morris, 2001, 89). ${ }^{2}$ Britain can be blamed, as in the McMahon Hussein Correspondence case, for being too quick to believe in vast religious conspiracies. Just as they believed in a vast Arab conspiracy, London believed in vast Jewish societies that controlled the world (Fromkin, 1989, 198). 
Ironically, the Zionist movement, which Britain believed to be the centre of world influence, was actually contained in four small rooms in Piccadilly Circus (Segev, 1999, 45). The Israeli journalist and historian Tom Segev (33) sums up the British aims in Palestine as follows:

The British entered Palestine to defeat the Turks; they stayed there to keep it from the French; then they gave it to the Zionists because they loved 'the Jews' even as they loathed them, at once admired and despised them and above all feared them...they believed the Jews controlled the world.

The Balfour Declaration was also quite possibly a British attempt to punish the Palestinians for not rallying behind the Great Arab Revolt and remaining loyal to the Ottomans during the war. Years later Lloyd George was asked if the British ever consulted the native Arab population on their views of the establishment of a Jewish homeland in Palestine. He sardonically replied, "We could not get in touch with the Palestinian Arabs as they were fighting against us" (Fromkin, 1989, 297).

I believe the main reason for Britain's own territorial aims in the Middle East, and the agreements they spawned, was an attempt to preserve the British Empire. In fighting the war, Britain used many resources from her colonies, especially Australia and New Zealand. As a reward for their services in the war, these nations pushed for their own autonomy and were granted it by sending their own delegations to the post-war negotiations (Mc Kale, 1998, 145). The loss of control of these parts of her empire made it even more important for Britain to build future colonies in the Middle East. Ironically, as Britain was attempting to end one empire, the Ottoman, she was attempting to preserve her own.

\footnotetext{
${ }^{2}$ It is beyond the scope of this paper, but in the 1948 Arab-Israeli War, Faisal's brother Abdullah similarly negotiated with the Israelis a division Palestine.
} 
Much has also been made of the harsh treatment the British gave the Arabs and Ottomans in the treaties ending the war. I believe this is also an unfair criticism. The Allies had an overwhelming feeling that they had just won a long and bitter struggle. They wanted to ensure the residents of their nations that this war had not been fought in vain. They also wanted to teach a lesson to all potential foes that starting another war against them was a foolish undertaking (Yapp, 1987, 290). Most of the Arabs remained loyal to the Ottoman Empire and fought against the British. The Entente wanted to show that this attempt had failed miserably and that severe punishment awaited all whom mimicked this attack. The Entente wanted to teach the very concept of Pan Islamism a lesson (Yapp, 1987, 290). But this was just not a social Darwinian attempt to punish the Orient for daring to challenge the power of Europe. It is important to keep in mind that the Allies were punishing their fellow European Germans just as badly, if not worse, than they were punishing the Ottomans and Arabs in the Middle East.

In a final analysis of the World War I wartime agreements, the contradictions cannot be blamed solely, or even mostly, on the British. The wording was vague, the promises were all contingent on actions of the other parties, and none of the provisions were to happen unless the war ended in an Allied victory. If we follow the letter of the law in these agreements, Britain did not contradict, or fail to live up to the conditions of any of the agreements. All of the parties were trying to defeat one another, none of the parties were living up to their promises in the treaties, and all of the parties were, despite what they said, only interested in bettering their own positions. If Britain can be blamed for anything, it is the mistaken belief that secret ethnic societies, that held vast power, could be tapped and led to a quicker Allied victory. In the end, the contradictory wartime agreements must be blamed on all the parties involved, not just the Western powers. 
Britain also receives criticism for a recreation of the Middle East following World War I. After all, it was with the war's conclusion that the Middle East was reshaped and recreated from a political arrangement under which Arabs had lived for 400 years. But like the wartime agreements, Britain should not receive much blame for the post-war settlements. Britain wished for a post-war set up that served her interests. When Britain realized that this ideal set-up was not possible, she decided that her interests could be safeguarded in another way, by compromise with people in society who would come to an agreement with the British to further their own interests (Hourani, 1991, 325). More often than not, this meant turning once again to her Hashemite allies. In fact, Britain's wishes for the post-war Middle East were in many cases quite different from the way the situation ended up.

On January 12, 1919, the United States President, along with his Secretary of State, met with the leaders of Britain, France and Italy in Paris. This is now considered the beginning of the varied proceedings grouped together under the general heading "Paris Peace Conference". The future of the Middle East was put on the back burner during the first part of the proceedings as most of the conference's energy was devoted to the European settlement. In fact, when the conference broke up in July, no decisions on the Middle East had been reached. Any decision on the Middle East was dependent on the United States' acceptance of mandates. By November, it was clear that the United States would not accept any responsibilities in the Middle East. Woodrow Wilson was anti-Mandate. It was anathema to his idea of self-determination. Wilson also wanted to prevent Britain and France from getting territory in the Middle East that they thought was their just reward for a war time effort in a region to which the United States never sent troops (Karsh \& Karsh, 1999, 267). In fact, Wilson was the first US president to leave 
the western hemisphere while he was in office. This action made Britain and France nervous (Fromkin, 1989, 390). Article 22 of the League of Nations Charter, an article that Wilson authored, said that the wishes of the former Ottoman subjects must be a "principal consideration" in selecting a mandatory power in Syria (Karsh \& Karsh, 1999, 267). Wilson proposed a commission be sent to the area and determine the will of the local residents. France and Britain both opposed this commission and it became a purely American venture. This King-Crane Commission visited Syria and reported that it was only the Catholic community that wanted French rule. They stated that an anti-French feeling was "deep rooted" in the Syrians. They uncovered "some evidence" that the French soldiers had attempted to keep some people from reaching the commission. The majority of the population wanted independence, or if a mandate was necessary, wanted the Americans or British, to have that mandate. The Zionists opposed the possibility of an American mandate because the US style of democracy ran counter to their plan for a national home in Palestine (Segev, 1999, 119). Nevertheless, this report was not published until 1922 and even then, it was mostly ignored. Wilson proclaimed that the United States would not accept a mandate for Syria. This was made official when the US congress did not approve US membership in the League of Nations.

Various Arab delegations made proposals for Syria, Lebanon and Palestine. There were three groups, two of them Christian, and one Muslim, that presented plans for the area. The first was the Central Syrian Committee of Shukure Ghanim, a Maronite delegation led by Emile Edde, who wanted the French to control Lebanon. A second Christian group, consisting of another Maronite delegation, wanted an independent Lebanon. The Sunni population of Lebanon, represented by Hussein's son Faisal, wanted independence for all Arab states south of the Taurus Mountains. Faisal did not want one 
large state, however, and believed that the Hijaz, Syria and Iraq should all remain separate entities. Faisal proposed an independent Syria, led by him, which also included the areas of Lebanon and Palestine. He pledged to offer concessions to minorities and privileges to the European powers in the area. France wished to stick by the Sykes Picot Agreement, which it now translated as a right to a mandate over all of Syria. Britain wanted substantial Arab independence in the interior of the region. At this time, the French started to believe that the British were bullying them in the Middle East (Yapp, 1987, 323). The King Crane Commission stated that the French thought the British cultivated the anti-French feeling in Syria. The French did not like the fact that the British were paying Faisal $\$ 750,000$ a month to govern Syria, $\$ 200,000$ of which went directly to Faisal for "personal expenses" (figures from King Crane Commission). British Prime Minister Lloyd George did wish to keep France out of the region (Karsh \& Karsh, 1999, 259). Even Mark Sykes, the coauthor of the Sykes Picot agreement believed that the agreement was no longer valid due to changing international events (Karsh \& Karsh, 1999, 261). The Prime Minister told France that they could not have Syria because Faisal's Arab army had liberated it and General Allenby was in charge. This was far from the truth. During the war, the British wanted Faisal's Arab troops to liberate Syria. They saw this as an ideal way to keep France out of the region. Faisal had become Britain's favourite of the Hashemite family because he, unlike his father, listened to British advice (Fromkin, 1989, 329). But it was the Australians who first entered Damascus. Faisal's forces did not enter until days later. As is mentioned above, the Hashemite rebellion was mostly ineffective. In fact, years later, Robert Graves was writing a biography of his friend T.E. Lawrence. Lawrence told him not to follow the version of the Arab revolt from his book The Seven Pillars of Wisdom because it was "full of half truth" (Fromkin, 
1989, 342). The newspapers in France went so far as to denounce British greed in the region. Lloyd George realized that France must be quickly appeased and an agreement was signed on September 15, 1919. The British began an evacuation of the area and gave a free hand in the settlement of Syria and Lebanon to France. Faisal protested but his complaints were disregarded.

At this time, the attitude of the Syrian Arabs began to change (Yapp, 1987, 324). During the war, the vast majority of the Syrians remained loyal to the Ottomans. Syrians had played a very small military role in the Arab revolt and very few participated in rebellious activities. After the war, the Muslims did not want French rule, whom they believed would favour the Christians. This distaste for French rule was an opinion also shared by the Greek Orthodox Christians who feared French rule would favour the Catholics. These groups allied their ambitions with the only credible rallying point against French rule, Faisal. Faisal set up an administration in Damascus. Faisal did not want the British to withdraw their troops and failing that, hoped that the United States would accept the Syrian mandate and support him (Karsh \& Karsh, 1999, 278-279). When the British withdrew, sporadic violence erupted throughout the country. Rival tribes were fighting for control of Syria in Faisal's name (Fromkin, 1989, 435). Faisal attempted to impress the Europeans by mobilizing political support. In November of 1919, he agreed with Clemenceau to accept French control of coastal Syrian and Lebanon in return for French acceptance for an Arab state in the interior. Once again, the Hashemites were giving away land in exchange for personal gain. With the election of Francois Mitterand this agreement was no longer possible. Mitterand was unwilling to give any part of Syria independence. On March 7, 1920, the Syrian Congress offered Faisal the crown of Greater Syria. Against Faisal's wishes, the congress also declared an 
independent Syria that included Palestine (Karsh \& Karsh, 1999, 284). The congress quickly signed and adopted a constitution. This was all unacceptable to France, who was officially given a mandate to rule Syria and Lebanon. This was also unacceptable to Britain, who had just received a mandate to rule Palestine. With the British forces gone, the French invaded Syria in July of 1920. On July 14, Faisal received an ultimatum to accept the French mandate, adopt the French system of currency, and to put an end to all anti-French activity. Faisal accepted these terms and on July 20 he left Syria for Palestine.

During the war, the area east of the Jordan River had been the area in which the army of the Arab revolt operated. Britain did not want to give France control of the region and proposed two possibilities for the region: to make it part of Palestine, or to let it become entirely independent. Britain decided that control of the area was too costly (Yapp, 1987, 330) and sent a handful of advisors to the region in August of 1920 to prepare the area for independence. In November, Faisal's brother Abdullah arrived in the region with 500 Bedouins form the Hijaz who were following an appeal from Faisal to help in his struggle with the French in Syria. The French asked the British to intervene militarily and stop them from moving to Syria, but Britain refused. The British feared the unrest in the region would give France an excuse to invade the area (Fromkin, 1989, 442). Britain felt by putting Abdullah in control of the area, they could keep the territory out of anarchy and keep the French out of the region (Karsh \& Karsh, 1999, 324). The Zionists were not happy with this proposed severing of the area they thought had been promised to them (Morris, 2001, 100). At the Cairo Conference in March of 1921, Transjordan was officially separated from Palestine and the British offered Abdullah a subsidy to rule the area. This subsidy was originally only to last six months, but with the 
lobbying of T.E. Lawrence, a permanent agreement was signed in 1923. The British originally wished for a temporary arrangement, at the end of which, Transjordan would become part of Palestine. Abdullah wished to use the area as a launching pad to build his own empire that would include Syria and Palestine (Karsh \& Karsh, 1999, 324). Neither of these plans ever came to fruition.

As a result of the war, Britain was in the strongest position of all powers in Arabia (Yapp, 1987, 337). Britain had not only protected her pre-war sphere of influence in the region, but had also increased her post-war control over Arabia by agreements with Kuwait and Qatar. Britain also managed to exclude the other powers from any influence in the region. Britain had no radical plans to resettle this region and wished to keep the status quo. The Sauds were becoming stronger and posed a potential threat to British interests in the area. At the Conference of Uqayr in 1922, Britain reached an agreement with the Sauds on their respective areas of influence in the region. Britain still considered Hussein to be an important ally in the region, but their embrace of Hussein began to wane. Hussein began to consider himself a King, and his sons Faisal and Abdullah, as viceroys of whom he was in control (Yapp, 1987, 338). After the British halted financial support to Hussein following the end of the war, he turned to a policy of strict taxation of merchants and pilgrims and became an unpopular ruler in the area. Hussein was then challenged by the Sauds for control of Arabia. When Hussein began to lose this struggle, he requested military aid from Britain. Britain refused military involvement, but sent T.E. Lawrence to present an offer to Hussein. The British offered to pay Hussein $£ 100,000$ a year as well as British support for his position in the Hijaz, if he would accept the provisions agreed to at the Cairo Conference. Hussein refused to accept the situation in Palestine and these negotiations went on for years. The British 
started to consider Hussein a nuisance. No longer having anyone they considered an ally in the region, the British decided to let the local powers settle the dispute and the Sauds eventually chased Hussein out of the region.

A state that began to emerge during the post-war peace settlement was Iraq. The British claims to Iraq are what Yapp calls "a series of logical accidents". The British wanted control of Basra for the defence of India, as well as for British prestige. The British then needed control of Baghdad for the defence of Basra, as well as British prestige. In turn the British then needed control of Mosul for the defence of Baghdad, as well as for British prestige. Britain received a mandate for Iraq in April of 1920. London decreed that Iraq should have a real measure of self-determination. The Iraqi uprising in October of 1920 interrupted these plans. This uprising started with the tribes of the lower Euphrates and spread throughout one third of the nation. To bring these areas under British control would mean large troop deployments and an expenditure of $£ 40$ million (Yapp, 1987, 335). The British commissioned Sir Percy Cox to set up a new system of government in Iraq. His solution was to install Faisal as the new head of government. Faisal met with King George V on December 4, 1920. Britain liked the fact that Faisal was anti-Ottoman and felt obliged to give him something after his assistance during the Arab Revolt. This solution was formalized at the Cairo Conference of 1921; the same conference at which Faisal's brother, Abdullah, was given control over the area of Transjordan. In the summer of 1921 , a referendum approved by $96 \%$ of the population of Iraq, made Faisal king. He ascended the throne on August 23, 1920. Faisal, and Cox for that matter, wished to replace the British mandate with a treaty. The British Cabinet did not accept this suggestion to void the mandate but did replace it to a large extent with the Anglo-Iraqi Treaty on October 10, 1922. This left Iraq independent subject to an 
overriding British control over finance, defence, foreign policy and various

administrative advisors. When the British replaced their ground forces in Iraq with Royal Air Force Units, part of Winston Churchill's cost-cutting program, the ordinary work of internal security fell to the Iraqis. With this, the Iraqi state quickly assumed the ordinary powers of an independent state (Yapp, 1987, 337).

British plans for the Middle East following the war did not end up quite the way they had planned. Winston Churchill, the Colonial Secretary at the time, opposed the Prime Minister's policies in the Middle East. He believed that Britain had neither the money nor the troop strength to coerce any type of settlement in the region (Fromkin, 1989, 494). The British soldiers, following the war, wanted to return home. In the summer of 1919, financial problems and social unrest at home, made the British withdraw their troops from Syria. The Times agreed saying that Britain needed to stop spending money abroad on foolish Middle East adventures, and start concentrating on the problems at home (Fromkin, 1989, 470). This led to a new make up of the Middle East that was not the ideal situation for which the British wished, but a series of compromises with France, the local Arab population, and most importantly, Britain's Hashemite allies. The new countries in the Middle East were not artificial British lines. They were artificial creations based on compromise between the imperial greed of the Hashemites and the British desire to defer to them when the British realized the realities of the region (Karsh \& Karsh, 1999, 351). Britain did not want the uprising in Iraq, Hussein to be chased out of Arabia, the unrest in Jordan, or the French mandate in Syria. It was due to the economic problems and social unrest at home and the hesitancy of the British public to accept another war in the Middle East, that led the British to place the Hashemites in power and hope for the best. As in the wartime agreements, the Hashemites deserve 
much of the blame for the failure of the post-war Middle East set-up. Despite the idealistic wishes of many, the Hashemites were not champions of Arab liberty. They were imperialists who wished to replace the Ottoman Empire with one of their own (Karsh \& Karsh, 1999, 349-351). It has often been said that the artificial borders of these new states ruined any potential for Arab unity. That is not the case. In fact, at this point in history, Arab nationalism was not directed against Europe in an attempt to build one Arab nation. It was directed at problems of identity and local political organization (Hourani, 1991, 310). The mistake the British made, besides once again committing themselves to the Hashemites, was in creating nations with larger borders than would have otherwise been possible (Karsh \& Karsh, 1999, 353-354).

It is perhaps Palestine that continues to be the source of the most unrest in the Middle East. The Ottoman Empire ruled the area of Palestine from 1517-1918. During this time, Palestine was never a separate administrative district. In the 1870 s, the area was part of Syria. In 1887 Jerusalem became an independent district directly ruled by Istanbul. The rest of Palestine became part of the villayet of Beirut. In the late Nineteenth Century, the Zionists began to purchase land from Arab landowners and some peasants (Kazemi \& Waterbury, 1991, 144). More land in Palestine was always available for purchase than the Jews could afford, and some of the sellers were members of the Arab nationalist movement (Segev, 1999, 273). As these land purchases began to dispossess some of the Arab villagers from their homes, the conflict began. The King Crane Commission stated that the Arabs had been friendly to the Jews who lived in Palestine prior to the Zionist program but would resist any future Zionist immigration. The Zionists wanted to be Europeans and always considered themselves to be better than 
the Arabs, and to the Jews who were living in Palestine prior to the Zionist immigration (Segev, 1999, 149).

In addition to the British, two parties were interested in Palestine. Faisal wanted Palestine to be part of an independent Syria. Weizmann wanted Palestine to be ruled by a British mandate that incorporated the program of the Jewish national home found in the Balfour declaration. Faisal and Weizmann met on May 31, 1918 in an attempt to find a compromise. In January of 1919, Faisal met with Weizmann and agreed that Palestine would not be part of the projected independent Arab state. He also agreed that some of the Jewish homeland programs would be implemented in Palestine, calling the Zionists “our Jewish cousins” (Morris, 2002, 80-81). Weizmann agreed that the Zionists would provide economic assistance to the Arabs as well as respect the rights of the Palestinian Arabs. The two signed a formal agreement on January 3, 1919 referring to the "racial kinship and ancient bonds" between Jews and Arabs and wishing for separation of Palestine from an independent Arab state (Morris, 2001, 80). When Faisal submitted his claim to the Paris Peace Conference, he asked for an independent Arab state in Syria that excluded Palestine (Morris, 2002, 81).

The League of Nations gave Britain the mandate in Palestine with explicit instructions to establish a Jewish national home in the region. The League of Nations created a committee to oversee the British rule in Palestine to ensure that Britain carried out the League's wishes. This committee had no real power and the British, for the most part, ruled as they pleased (Segev, 1999, 161-162). The British realized early on that they could not create any type of government that would accommodate both the Arabs and the Zionists so they decided to retain direct military control of Palestine (Hourani, 1991, 331). In the end, no one was happy with the situation in Palestine. The Arabs were 
upset that Palestine had been separated from Syria and did not become a part of an independent Arab area. The Zionists were not happy that Transjordan had been separated from Palestine (Segev, 199, 158-159). Even the British on the scene were not happy with the outcome. The King Crane Commission said that "many officials" including General Allenby wanted an American mandate in the region so that Britain could escape from the region's problems. The British military saw Zionism as a nuisance and did not want conflict with the Arabs (Segev, 1999, 86) and despised the civilians in London telling them what to do (Segev, 1999, 63-64). These four sides, the Arabs, the Zionists, British officials in London, and the British army in Palestine were on a collision course.

While the League of Nations was debating the mandate, the first violence in Palestine broke out. The British investigated the source of this violence and blamed the Jews. The military halted Jewish immigration and raided the Zionist offices. This angered the Zionists. Richard Meinertzhagen, the political officer to General Allenby, claimed that the British military initiated the riots to prove that Zionism was an unsound policy (Segev, 1999, 140). The Zionists became even more angered when all Arabs arrested in this violence were released they the British military (Segev, 1999, 98). The Zionists claimed that the British officials in Palestine were not carrying out the instructions of the British officials in London. The British officials on the scene tried to play the middle road and appease both sides in an effort to prevent violence. This was a pattern that would continue.

Throughout the British mandate in Palestine, both sides would protest British actions, accusing the authorities of favouring the other side. In May 1921, there were more riots in Jaffa. This led to a British commission of inquiry that blamed the Arabs for the violence, but gave them a great deal of understanding (Segev, 1999, 187). Following 
the violence in Hebron in 1929, the British chancellor issued a report condemning the violence and blaming the violence solely on the Arabs. The Arabs complained at this unfair treatment so the commission issued a second, less harshly worded statement, which caused the Zionists to protest (Segev, 1999, 327).

In response to the 1929 riots, the British issued the Passfield-White Paper on October 21, 1930. This reduced the commitment of the Balfour Declaration and limited Jewish immigration to that which the region could absorb economically. Some of the Zionists began to believe the British were not only betraying them, but would not protect them against the Arabs. This led to the formation of the Haganah, a Zionist defensive force, and the Irgun Bet, which split from the Haganah and wished to be aggressive against the Arabs (Morris, 2001,118).

The next major violence in Palestine occurred in 1936. This coincided with the largest Jewish immigration to Palestine, 60,000. This violence was different than the first in that it occurred mostly in the rural areas of Palestine. The Arabs participating in this violence were almost all peasants, and many prominent Arabs in the rural regions left for the cities during these uprisings (Kazemi \& Waterbury, 1991, 164). The British government in London wanted the British forces to refrain from responding to this uprising, believing that the violence would subside on its own. The British military officials in Palestine wanted to crush it and thought the officials in London were weak. The Zionists wanted to sit out and let the British army take care of it (Morris, 2001, 131136). The villagers who stayed in the area and did not participate in the violence were left in a dilemma that is still a problem in Palestine to this day. If they gave cover to the rebels, they faced punishment from the British military; if they turned the terrorists over 
to the British authorities, they faced reprisal from the rebels (Kazemi \& Waterbury, 1991, 423).

During this time, the attitude of the British in London began to change. The conventional wisdom in London was that the British had erred in supporting Zionism (Segev, 1999, 37). In 1937, the British sent the Peel Commission to Palestine to study the problem. The 404-page report concluded that the conflict between the Arabs and Zionists was insoluble within one state and that the region should be partitioned into two separate states (an idea that is still a proposed solution to this day) with an exchange of population that would transfer 225,000 Arabs and 1250 Jews. The Zionists and Arabs did not support this idea. The Arabs refused because they could not decide on what part of Palestine to give the Zionists. The Zionists kept asking for more land. Ironically, this situation is reversed today. The Israelis cannot decide what territory to give the Palestinians, and the Palestinians keep asking for more. Finding no basis for compromise, these suggestions never became reality. The Woodhead Commission, which followed the Peel Commission, stated that partition could not be implemented because no one wanted it. The British began to see Zionism as another form of ultra nationalism and one of the commission's members, Thomas Reid, said,

Zionism is not a wise movement for the Jews to foster. It is the same nationalism that we object to in Hitler. The solution to the Jewish problem (is) assimilation (Morris, 2001, 156).

This idea of assimilation into one state with an Arab majority would be repeated in 1939 with another White Paper. This called for a bi-national state established with an Arab majority. It proposed limiting Jewish immigration to 75,000 within ten years. The Arabs were happy with this plan while the Zionists were furious. With the outbreak of World War II, the British believed that they would need Arab support in a potential Axis 
invasion of the region. The British believed that the Zionists had no choice but to support Britain in the conflict with the Nazis. British Prime Minister Neville Chamberlain summed up this position when he said,

If we must offend one side, let us offend the Jews rather than the Arabs (Morris, 2001, p. 158).

This policy did not prevent the Arabs from siding with the Nazis during the war. Despite the fact that Hitler had called Arabs "half apes" (Morris, 2001, p. 165), the Arabs made a deal with the Germans in November of 1941, much as Sharif Hussein made with the British in the previous world war; if the Arabs helped the Germans get the British out of Palestine, the Germans would grant them independence in the region following the conclusion of the war (Morris, 2001, 166). At any rate, the Germans lost the war so one can only speculate if Hitler would have honoured this agreement. This policy never did go into effect due to the outbreak of World War II, but it did have one very serious consequence; it caused the Zionists to attack the British in Palestine. In February of 1944, the Lechi Group, a Zionist terrorist organization, declared war on the British (Segev, 1999, 477). Just as had been the case in the Arab terrorist attacks, the British military wanted to crush the Zionist terrorists, while the government in London urged restraint.

Just as they had wished to become involved in Palestine following the conclusion of the First World War, the British wished to leave Palestine following the conclusion of the Second World War. An Anglo-American Committee of Inquiry went to the region to once again look for a solution to the problem. The committee decided that the idea of partition was unworkable and that the region should be split into a bi-national framework with the mandate continuing with the United Nations (Morris, 2001, 178). On February 14, 1947, the British cabinet decided to turn the mandate over to the United Nations and 
cleanse themselves of the problems of Palestine. The United Nations proposed to partition the area (a plan with which neither the Jews nor Arabs were happy) and this plan passed by a vote of 33 in favour (including the United States and USSR) and 10 opposed. There were ten abstentions, including Great Britain. With this vote, British direct involvement in the Middle East concluded.

An analysis of the British mandate in Palestine is much like the analysis of other British involvement; all sides must share in the blame for the problems. The Ottomans and Arabs must be blamed for selling land to the Zionists; the Hashemites must be blamed for once again, selling out the Arabs in an attempt to further their own cause; the Zionists must be blamed for considering themselves colonizers out to civilize the Arabs; both the Zionists and Arabs must be blamed for not wanting to compromise (something of which they can still be blamed today) and the British must be blamed for once again trying to find compromise and playing both sides of the issue.

The history of this period offers the United States many lessons that it should consider when formulating its foreign policy today.

Pan-Arabism (Islam) is not a credible threat. The British fear of a Pan Arab revolt that would threaten her holdings in Egypt and India led the British to contact Sharif Hussein in an attempt to use this power for Britain's own good. The revolt was an expensive military failure and this alliance with the Hashemites brought Britain many problems after the war. Today, we still hear this fear from the United States. Prior to the Gulf War, the experts predicted a disaster in the region. There would be upheavals in every Arab country; Americans would be slaughtered in the streets; the Arab world would unify and turn its weapons against the United States. None of this happened (DeAtkine, 1993, 53). This opinion has also been reiterated in the current war on 
terrorism. Yet the historical record shows that this idea of Arab unity is merely a myth.

The so-called Arab Revolt never culminated in the mass rebellion the British believed would happen. In The 27 Articles of T.E. Lawrence, an instruction manual for British officers in the Middle East, the author said,

A sheikh from one tribe cannot give orders to men from another...Do not mix Bedou and Syrians, or trained men and tribesmen...I have never seen a successful combined operation, but many failures.

Following the conclusion of World War I, the King Crane Commission discove red that the Syrians did not want a union with the Hijaz, or Mesopotamia for that matter, because they believed that Syria was in a more advanced state of civilization than either region. Ironically, the Hashemites believed that the only real Arabs came from the Arabian peninsula and that the Palestinians and Syrians were backward people. During the violence in mandated Palestine, more Arabs were killed by other Arabs in inter-tribal looting than were killed by the British or Jews (Morris, 2001, 151). In addition, several Arabs, including some mayors accused of collaborating with the Jews or the British, were killed by Arabs (Segev, 1999, 369). This same situation is repeating itself today during the current conflict. Suspected collaborators are dragged from their cells and shot at point-blank range. Nationalism never developed into Pan Arabism because each nation was subject to a different type of colonial rule. Because of this, each nation developed a separate national movement that was not unifiable with the others (Hourani, 1991, 342). Just as the Sultan's cry for a holy war fell on deaf ears during World War I, Sadaam Hussein's cry for a holy war against the US-led coalition fell on deaf ears during the Gulf War. I have always considered the idea that all Arabs and Muslims think and act alike and will join together to fight the "other" a racist idea. We do not ever hear about Pan Christianism, or Pan Europeanism or even Pan Asianism, Pan Africanism, or Pan 
Latinosim. This "fear" should not be considered when the United States formulates its foreign policy.

The belief in Pan Judaism is equally invalid. Just as there was not, and is not, a vast Arab movement, the existence of a vast Jewish movement also proves to be a false belief. The Balfour Declaration did not cause this imagined Jewish conspiracy to convince Russia to stay in World War I, it did not get the United States to declare war against the Ottomans, and it did not get the Americans to accept a mandate in the region. Even during the early days of Zionism, the Jews were not a united movement. Most of the Jews who lived in Palestine before the Zionist emigration were ultra-Orthodox people who did not support the secular idea of Zionism. The Zionists did not accept the ultraOrthodox personnel who had no income and were dependent on donations from Jews back home (Segev, 1999, 16). Weizmann even went so far as to state his distaste for Jerusalem and "the old Jews" who lived there, believing they were "no better" than the Arabs living in Palestine (Segev, 1999, 70-70). During the mandate, the Zionist leaders continued to prefer the rural areas believing that the Kibbutzim were the guardians of the land and that it was these settlements that would determine the future borders of the Jewish national home. The Zionists pushed agriculture in the education program believing that a broad education would encourage the populace to leave Palestine (Segev, 1999, 249-259).

During the height of Jewish immigration to Palestine, only one out of every 4000 of the world's Jews came to Palestine, and that was only when the United States closed its doors to immigration in 1924 (Segev, 1999, 225). The Zionists, although wishing for a high number of immigrants to create a Jewish majority in Palestine, did not want anyone without money showing up (Segev, 1999, 229). In 1923, Jabotinsky left the 
Zionist party and created the Revisionist party. This new party believed that the Zionists were not doing enough to further the cause and called for more immigration and a more militant stance against the Arabs. Ben Gurion called Jabotinsky the "Fascist Satan" and his Revisionist party “a party of Nazis” (Segev, 1999, 386). Even during the Holocaust, an event that should have united the Jews of the world, Ben Gurion said, "The catastrophe of European Jews is not, in a direct manner, my business" (Segev, 1999, 162). Even today the Israeli government is far from united in backing Sharon's policies and his military commanders have even refused to carry out some of his orders. Just as the belief that the Arabs are somehow all alike and united, the belief that the Jews are all alike and united is a racist idea that does not need to be considered in the formulation of United States' foreign policy.

Money buys neither happiness, nor loyalty. The British spent a quite substantial sum funding the Arab revolt with limited results and no creation of a pro-British Arab populace. The Western powers seem to believe that throwing money at people in the Middle East (and other regions of the world) will solve all of the problems. In fact, it was the supposed wealth of the world's Jews that would bring untold riches to the Arabs of Palestine that was a consideration in the Balfour Declaration. The Arabs who sold land to the Zionists did not become pro-Zionist or even welcome them into the area. The United States is continuing this incorrect line of thinking. Many in the United States today believe that free trade and economic aid will create a stable, friendly region. This is not happening. Saudi Arabia, while supporting US strategic interests, encourages their state-controlled media to demonize America as a way to redirect anger from the Saudi's political failures (Hoffman, 2002, 86-87). Al Ahram, the leading newspaper in Egypt, a big recipient of US foreign aid, published a story suggesting that the United States 
poisoned relief packages and dropped them in mine fields in Afghanistan (Hoffman, 2002, 88). In the November/September edition of Foreign Affairs, Fouad Ajami, a Professor at Johns Hopkins University, wrote:

The United States could grant generous aid to the Egyptian state, but there would be no dampening of the anti-American fury of the Egyptian political class...On September 11, 2001, there was an unmistakable sense of glee and little sorrow among upper class Egyptians...only satisfaction that America had gotten its comeuppance... There will be chameleons good at posing as America's friends but never turning up when needed.

Israel, the largest recipient of US foreign aid, can also be added to this list. Despite pleas from the Bush administration, the Israelis seem more intent than ever to increase settlements and crush the Arabs militarily. While it would be foolish to suggest a total abandonment of free trade and economic assistance, the US would be wise to reformulate the conditions that are attached to foreign aid. While this would be seen in the short run as US arrogance in insisting that everyone become more American-like, in the long run, it would ensure that the Middle East become more affluent and democratic. Mere monetary aid, without an accompanying program of nation-building, will not end this cycle of antiAmericanism.

Dealing with leaders in the Middle East is a precarious undertaking. The British did not wish to spend the money and manpower at stabilizing the Middle East so they looked for friendly leaders upon whom they could use to protect their interests. In his 27 Articles, T.E. Lawrence wrote that the British should "wave a Sharif in front of you like a banner and hide your own mind and person". The British followed this advice and developed a relationship with the Hashemite family, a policy that would ultimately fail in all nations but Jordan. Yet it is not merely the Western-oriented political leaders that added to the instability of the Middle East; it was also a new class of people that began to arise in the late Nineteenth Century, the economic elites. As the Ottoman 
Empire lost power vis a vis the European powers, many people in the Middle East were exposed to the western way of life. As people went to Europe and received European educations in European languages, they would return to the Middle East and establish new Western-style schools in the rural areas. At the same time people in the urban areas were talking about Arab nationalism and Islamic reform, people in the rural areas were producing works of Islamic theology and learning (Hourani, 1991, 311). The urban schools created educated elites whose economic interests lay with the West, but the rural religious schools continued to create people educated in the traditional, religious way of life whose interests were not associated with the West (Hourani, 1991, 348). Yet this disparity was not simply rural versus urban. The Ottoman Empire introduced the idea of land ownership as part of the Tanzimant Reforms. This split the rural areas into two groups: large estates with irrigation, and small farms without irrigation (Hourani, 1991, 334-335). Coupled with this economic disparity, modernization also reduced the power that local elites had enjoyed for so long. This system of direct rule arrived first in the urban areas. At this time the local rural leaders, men of religion, still had some authority. When direct rule spread to the countryside, some of these elites led a rebellion that had a religious fervour (Hourani, 1991, 312). It was Sharif Hussein of Mecca, a religious leader threatened by the modernization of the Ottoman Empire, who turned to Great Britain to help him from losing his power. In the present day, most of the religious militants still come from the rural areas. It is easy to see these militants as religious zealots and their religion as the cause of their anger, but the real cause of this anger is economic disparity. Until this disparity is alleviated, this anger will continue. The process of modernization and the rebellion it bred is being repeated today with the process of globalization. It is not surprising that the activity of these militants has 
increased in recent years with the global economy upsetting traditional ways of life. America is often criticized for supporting pro-West leaders such as Hosni Mubarak of Egypt or King Abdullah of Jordan, but is unfairly criticized for not supporting the legitimacy of leaders such as Yasser Arafat or Sadaam Hussein. While dealing with leaders in the Middle East is far from perfect, it is really the best that one can do.

The Arabs benefit from Western involvement. It is a long-held belief that the Western world has always favoured the Zionists/Israelis in the conflicts in the Middle East. During the mandate, the British made many conflicting decisions, some that benefited the Jews and some that benefited the Arabs. The Zionists never got all they wanted and constantly accused the British authorities in Palestine of favouring the Arabs (Segev, 1999, 64). The Arabs rejected the UN partition idea in 1948, believing that in a war, they would drive the Jews to the sea. Not only did this not occur, but also it is this very idea of partition that is at the top on most Arab's list for a peaceful solution to the Palestinian problem. The Jews, coming to believe more and more that the British were the problem, wanted the British out. Today, it is the Palestinians and some within the Arab world, that urge the United States to make Israel withdraw from the occupied territories or halt their military incursions into the Arab camps. Frustrated with the decisions of the Israeli government, the Palestinians resort to violence to coax an outside power to intervene and force a more favourable political solution (Ajami, 2001, 13). In perhaps the greatest of ironies, frustrated with what they see as a pro-Israeli United States, the Arabs are turning to the European Union (from which the idea of Zionism and the mandate system came) as a possible third party to solve this crisis on terms favourable to the Arab side. Nevertheless, as fifty years of losing wars have taught them, it is only the Western powers that can coerce Israel into doing anything. 
The Middle East is a xenophobic region. Writing to British officers serving in the Middle East in 1917, T.E. Lawrence said, "The foreigner and Christian is not a popular person in Arabia". This feeling began to emerge, as many other problems in the region, with the process of modernization. As Europe began to surpass the Ottoman Empire as an economic and military power, the Muslims in the area began to wonder how they could remain Muslims, but compete with the Western infidels. The Christians of the region never had this problem and began to secede from the empire. In order to preserve the empire, Ottomanism (a reaction to European nationalism) began to take on more of an Islamic fervour (Hourani, 1991, 306-309). In addition, as the empire became more interactive with the West, some Europeans immigrated to the Ottoman Empire. In the countries with large European populations, these foreigners controlled finance, industry, foreign trade, and more and more, the land (Hourani, 1999, 322). The economic disparity was worsened by the fact that in many cases, the economic elites were foreigners. The Arabs have always maintained that they got along fine with the Jews in the Middle East until the Zionists, who were in reality Western colonialists, started immigrating to Palestine. In his book What Went Wrong, Bernard Lewis describes the xenophobia that emerged as the Ottoman Empire began to lose power vis a vis the European powers. Lewis (152) says, "It is usually easier and more satisfying to blame others for one's misfortunes". Indeed, many people in the region blame the decline of the Ottoman Empire, and the subsequent failings of the Arab world, on Western encroachment. Yet this rise in Europe's powers would not have been possible if the Ottoman Empire had not first declined. This situation is continuing today as many state elites in the Middle East wish to divert criticism from their own inept regimes to the United States, the convenient scapegoat of all Middle Eastern blame. I have argued through this paper that the 
problems in the Middle East are partly due to Arab mistakes. As long as the Arabs continue to blame the "other" for their problems, they won't be able to find solution to these problems. In the conclusion to What Went Wrong, Lewis (159-160) says,

If the peoples of the Middle East continue on their present path, the suicide bomber may become a metaphor for the whole region, and there will be no escape from a downward spiral of hate and spite, rage and selfpity, poverty and oppression, culminating sooner or later in yet another alien domination; perhaps from a new Europe reverting to old ways...If they can abandon grievance and victimhood...then they can once again make the Middle East... a major center of civilization...the choice is their own.

Proponents of 'Terror Management' give us a psychological view of this xenophobia. According to this theory, people are driven by a desire to stay alive. A person's worldview has to give them a belief that behaviour and outcomes are related in a just way. If one lives up to these values, then one will experience positive outcomes and eventually transcend death. This encourages people to not only wish large rewards on those who share their worldview, but also to inflict harsh punishments on those wicked ones who do not share their worldview. The others who express different worldviews, challenge the very worldviews people hold. Often, this perceived challenge to one's worldviews results in prejudice. It is no surprise that in the Middle East, where many people fear for their very survival, people turn to religion as a way to make the world a just place. And it is also not surprising that the infidel West becomes the target of this rage. If the fear for survival were to be alleviated with stable economic and political systems, the terrorist's cries for killing the infidel West would fall on deaf ears.

The Western powers are more balanced than they get credit for. Just as the Arabs benefit from Western involvement, the Western powers are more balanced than many in the Middle East believe. People often point to the Balfour Declaration as the penultimate example of Western preference for the Zionists. Or course, this argument is 
invalidated when we remember that Arabs and Ottomans were selling land to the Jews years before the Balfour Declaration was even a consideration. And Faisal's wish for an independent Syria excluding Palestine, which would become a national home for the Zionists, also invalidates this claim. During the period of the British mandate, the British made many decisions that favoured the Arabs and many that favoured the Zionists. Of course, playing this middle road caused both sides to accuse the British of an uneven handed policy. This continues to the present day. We read comments in the Arab newspapers that the US is,

reshuffling the cards to achieve an objective sought by (its) Zionist team (Al Thawrah (Iraq) November 29, 2001).

And, in the September 13 issued of Al-Hayat, a Saudi daily published in London,

As for (Americans) deducing the implications (of 9-11), it is unlikely to occur, because the Zionist mind - which manages the US machinery through politics, money, and media -will not permit it. The logical deduction should question why the United States in particular? Why its people? What is the main concealed Israeli secret behind it?" (italics mine)

Ironically, our Zionist Israeli clients do not see it that way. We can read in the editorials of the Jerusalem Post, an English language newspaper that is anything but a right-wing publication,

the Western press, so wondrously evenhanded over the years regarding events in Israel that it has created the intellectual underpinnings on which Palestinian terrorism flourishes (April 1, 2002)

(the) New York Times (portrayed) Idris (a female suicide bomber) as someone who 'raised doves and adored children'...(not as someone) whose goal was to murder as many innocent Israelis as possible...the media frequently commit sins of omission (March 3, 2002)

the US is so worried about Arab opinion it is willing to protect Arafat's terrorist regime for its ally Israel (March 18. 2002) 
This last comment is the most interesting. Just as Britain decided that they needed to make concessions to garner Arab support during World War II more than they needed to garner the support of the Jews, who had no choice but to support Britain, the US is now being criticized for selling out Israel in order to garner Arab support for a possible strike on Iraq. If we look at George Bush's speeches, this even-handedness is obvious. The President addressed the United Nations on November 10, 2001 and declared,

We are working toward a day when two states, Israel and Palestine, live peacefully together within secure and recognize (sic) borders as called for by the Security Council resolutions.

The President added to this on April 4, 2002 by saying,

The United States is on record supporting the legitimate aspirations of the Palestinian people for a Palestinian state...The outlines... are clear: two states

On September 17, 2001, the President quoted from the Koran and said "Islam is peace." President Bush also quoted from the Koran on November 15, 2001 and extended a Ramadan greeting to Muslims. If anything the media in the United States, with the freedom of speech and the press, is more objective and even-handed than the nations of the Middle East. Yet, despite this, the United States needs to be more balanced. America needs to take a more hard- line approach with the Israelis. It was US pressure that caused the Israelis, as well as the British and French, to withdraw from the Suez Canal in 1956. It was the threat to withhold American aid that caused Israel to halt the advance into Lebanon. The United States should not only vote against Israel in the United Nations, but should use US might to ensure Israeli compliance with UN resolutions. This combination of threat and pressure has worked in the past and it will work again. It is only high profile decisions that demonstrate US objectivity that will assuage the feeling of anti-Americanism that seems pandemic in the Middle East today. 
The Middle East is millstone around our necks. Although I find it problematic to criticize a nation state for the foreign policy it chooses to follow in order to further its interests, the Untied States is in a different situation than any other nation state. While it may be tempting to suggest, and I am sure many a US policymaker has dreamt, that the US simply revert to an isolationist shell and leave the Middle East to its own devices, the US simply cannot do that. As the only remaining super power, the United States has a moral obligation to use its wealth and might to make the world a better place. Just as America used the Marshall Plan to rebuild Europe following World War II, the US needs to build a better Middle East. A good place to start would be to make all of this talk of a Palestinian state a reality. This would regain some of the lost credibility with many in the Arab world. When implementing foreign policy in the region, the United States needs to keep in mind the xenophobia of the Middle East. America cannot appear to be forcing any decision. In fact, T.E. Lawrence's words of finding a Sharif to hide behind would be an excellent idea. At the end of World War II, the British knew the era of Empires and colonialism was coming to an end and followed new policies of mandates and imposing friendly monarchical rule in order to stabilize the Middle East and protect Britain's interests. It is clear today that these policies have failed and a new policy is needed. The United States should look for its own brand of Hashemite allies. But unlike the Hashemites, who were self-interested and willing to make any concession that bettered their own situation, the United States must find people who are more interested in bettering the region as a whole than bettering their own personal situation. Sadly, America seems to have found their own self-interested allies today and the end result of this situation will inevitably be the same as the British policy of self-interested allies; instability. If the United States can find regional leaders of legitimacy in the Middle 
East, leaders who are interested in using American money and might to build stable nations in the Middle East, this unending cycle of violence, militant Islam, military strongmen, terrorism and extreme xenophobia, and wars may become true history; not mistakes of history that will be continually analyzed as new powers become embroiled in the problems of the Middle East. 


\section{REFERENCES}

Ahmad, Imam. "Bush Can Fool No One.” Al Thawrah. November 29, 2001

Ajami, Fouad. 2001. “The Sentry’s Solitude.” Foreign Affairs. Vol. 80 No. 6:2-16.

Al-Zaatra, Yasser. "England: Does America Read The Signs?" Al-Hayat. September $13,2001$.

Appleyard, Bryan. "Why Do They Hate America?" The Sunday Times Online. September 23, 2001.

Bush, George W. The East Room. October 11, 2001.

Bush, George W. Islamic Center of Washington D.C. September 17, 2001.

Bush, George W. The Oval Office. February 7, 2002.

Bush, George W. President's Message for Ramadan. November 15, 2001.

Bush, George W. The Rose Garden. March 7, 2002.

Bush, George W. The Rose Garden. April 4, 2002.

Bush, George W. Thurgood Marshall Extended Elementary School. October 25, 2001.

Bush, George W. The United Nations. November 10, 2001.

“Bush, Mubarak Pledge Redoubled Peace Effort.” CNN.COM. March 6, 2002.

“Cheney’s Challenge”. Editorial. The Jerusalem Post. March 18, 2002.

DeAtkine, Norvell B. "The Middle East Scholars and the Gulf War.” Parameters. Summer 1993: 53-63.

Dudkevitch, Margot. "Palestinians Execute 11 Suspected Collaborators." The Jerusalem Post. April 2, 2002.

Esposito, John. 1991. Islam and Politics. Syracuse, NY: Syracuse University Press.

Farah, Caesar. 2000. Islam. Hauppauge, NY: Barron's Educational Series.

Farrell, Stephen. "Sharon and His Defence Chief Clash Over Raids." The Times. March 14, 2002.

Fisher, Sydney Nettleton \& William Ochsenwald. 1997. The Middle East. A History. Volume II. New York: McGraw-Hill. 
Friedman, Thomas L. "Breaking The Bargain Of Autocrat And Mullah". The New York Times. November 18, 2001.

"Friends Like These." Editorial. The Jerusalem Post. April 1, 2002.

Fromkin, 1989, David. 1989. A Peace to End All Peace. The Fall Of the Ottoman Empire and the Creation of the Modern Middle East. New York: Henry Holt and Company LLC.

Gellner, Ernest. 1983. Nations and Nationalism. Ithaca, NY: Cornell University Press.

Hechter, Michael. 2000. Containing Nationalism. New York, NY: Oxford University Press.

Hoffman, David. 2002. “Beyond Public Diplomacy.” Foreign Affairs. Vol. 81 No. 2: 8395.

Holsti, K.J. 1996. The State, War, and the State of War. Cambridge: Cambridge University Press.

Hourani, Albert. 1991. A History of the Arab Peoples. Cambridge, MA: Belknap (Harvard University) Press.

Hunter, Shireen T. ed. 1988. The Politics of Islamic Revivalism-Diversity and Unity. Bloomington, IN: Indiana University Press.

Huntington, Samuel P. 1968. Political Order in Changing Societies. New Haven: Yale University Press.

Karsh, Efraim and Inari Karsh. 1999. Empires of the Sand. The Struggle For Mastery in the Middle East 1789-1923. Cambridge: Harvard University Press.

Kayali, Hassan. 1997. Arabs and Young Turks. Berkeley, CA: University of California Press.

Kazemi, Farhad \& John Waterbury. 1991. Peasants \& Politics in the Modern Middle East. Miami: Florida International University Press.

The King Crane Commission Report. 1922. Editor and Publisher. Vol. 55 No. 27

Kinross, Lord. 1977. The Ottoman Centuries. The Rise And Fall Of The Ottoman Empire. New York, NY: Morrow Quill Paperbacks.

Lawrence. T.E. “The 27 Articles of T.E. Lawrence.” The Arab Bulletin. August 20, 1917.

Lawrence, T.E. "Personal Notes On The Sheffifial Family." The Arab Bulletin. November 26, 1916. 
Lawrence, T.E. “A Report On Mesopotamia.” The Sunday Times. August 22, 1920

Lewis, Bernard. "The Roots Of Muslim Rage." The Atlantic Monthly. September, 1990.

Lewis, Bernard. 2002. What Went Wrong. Oxford: Oxford University Press.

Marston, Frank S. 1981. The Peace Conference of 1919. Westport, CT: Greenwood Press Publishers.

McKale, Donald M. 1998. War by Revolution. Kent, OH: The Kent State University Press.

“The Media And The Middle East." Editorial. The Jerusalem Post. March 3, 2002.

Morris, Benny. 2001. Righteous Victims. A History of the Zionist-Arab Conflict 18812001. New York: Knopf.

Plotkin, Robert. “Witness To Jenin Justice.” The Jerusalem Post. April 24, 2002.

Powell, Colin L. CBS's Face the Nation. March 10, 2002.

“Powell Questions Sharon’s Tactics.” The Jerusalem Post. March 7, 2002.

"Powell's Misfire." Editorial. The Jerusalem Post. March 8, 2002.

Prszczynski, Tom, Jeff Greenberg, \& Sheldon Solomon. 1997. "Why Do We Need What We Need? A Terror Management Perspective on the Roots of Human Social Motivation." Psychological Inquiry. Vol 8 No. 1:1-20.

Rejwan, Nissim. 1998. Israel's Place in the Middle East. A Pluralist Perspective. Gainesville, FL: University of Florida Press.

Segev, 1999, Tom. 1999. One Palestine Complete. Jews and Arabs Under the British Mandate. New York: Henry Holt and Company LLC.

Smith, Tony. 2000. Foreign Attachments. The Power of Ethnic Groups in the Making of American Foreign Policy. Cambridge: Harvard University Press.

Watson, Roland \& Stephen Farrell. "Bush Urges Sharon To Ease The Palestinian Plight." The Times. March 6, 2002.

Yahya, Mohammad. 1985. A Criticism Of The Idea Of Arab Nationalism. Al Tawhid. Vol. III No. 2.

Yapp, Malcolm E. 1987. The Making of the Modern Middle East 1792-1923. London: Longman House. 